\title{
First Report of Genotype E of Hepatitis B Virus in an Indian Population
}

\author{
Jasbir Singh ${ }^{\mathrm{a}}$ Caroline Dickens ${ }^{\mathrm{c}}$ Vikas Pahal $^{\mathrm{a}}$ Rajesh Kumar $^{\mathrm{a}}$ \\ Rajender Chaudhary ${ }^{b}$ Anna Kramvis ${ }^{c}$ Michael C. Kew ${ }^{d}$

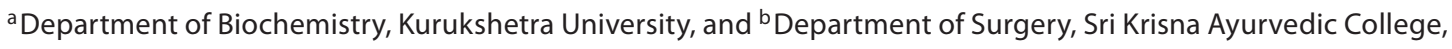 \\ Kurukshetra, India; ${ }^{C}$ Hepatitis Virus Diversity Research Programme, Department of Internal Medicine, \\ University of the Witwatersrand, Johannesburg, and ${ }^{\mathrm{d}}$ Department of Medicine, University of Cape Town, \\ Cape Town, South Africa
}

\section{Key Words}

Hepatitis B virus · Precore mutations · North Indian

population

\begin{abstract}
Twenty-one hepatitis B virus (HBV) isolates from the state of Haryana (North India) were studied for genotype, subgenotype, serotype distribution and precore mutations. Assays of alanine aminotransminase (ALT) and $\mathrm{HBeAg}$ were performed on all samples. Genotypes, subgenotypes and serotypes were determined by amplification of pre-S1/S2 regions followed by RFLP and also by phylogenetic analysis of amplified products. Mutations were studied by amplification and sequencing of the precore region. Twenty-four percent of the samples had high ALT levels and $90 \%$ were HBeAg negative. It was observed that $90 \%$ of the samples were HBV D genotype, (subgenotype D1, serotype ayw2), 5\% HBV A genotype (subgenotype $A 1$, serotype $a d w 2$ ), and the remaining 5\% were HBV E genotype (serotype ayw4). The subgenotype A1 was quite similar to the South African isolates. Phylogenetic analysis of the HBV isolates, based on the preS1/S2 gene sequences, confirmed genotype E. Amplification and sequencing of the precore region showed $1762^{\mathrm{A}-\mathrm{T}}$ and $1764^{\mathrm{G}-\mathrm{A}}$ mutations in 38 and $15 \%$ of the samples, respectively. $1809^{\top}$ was observed in $5 \%$ of the cases under study. This
\end{abstract}

is the first report of the genotype $E$ of hepatitis $B$ virus in the Indian population. Efforts are underway to amplify and sequence the full length of this genotype $E$ isolate.

Copyright $\odot 2009$ S. Karger AG, Basel

Hepatitis B virus (HBV) is a noncytopathic, hepatotropic DNA virus which belongs to the family Hepadnaviridae. It remains an important cause of morbidity and mortality worldwide, especially in developing countries. $\mathrm{HBV}$ infection leads to a wide spectrum of liver conditions including acute self-limited infection, inactive carriers, fulminant hepatitis and chronic hepatitis, with eventual progression to cirrhosis and hepatocellular carcinoma [1]. It is estimated that over 400 million people worldwide are infected chronically with HBV. The virus has a small-sized genome (approximately $3.2 \mathrm{~kb}$ long) arranged in a circular, partially double-stranded DNA molecule. The viral genome contains 4 open reading frames encoding the envelope, pre-C/C, polymerase and X proteins.

There are at least 8 genotypes of $\mathrm{HBV}$, designated A$\mathrm{H}$, based on a divergence of $>8 \%$ over the entire genomic sequence. There are significant differences in the worldwide distribution of these different genotypes [2-4]. India falls into the intermediate endemic zone with regards to the prevalence of $\mathrm{HBV}$ infection. The reported HBsAg

\section{KARGER}

Fax +41 613061234

E-Mail karger@karger.ch

www.karger.com
(C) 2009 S. Karger AG, Basel

0300-5526/09/0525-0235\$26.00/0

Accessible online at:

www.karger.com/int
Jasbir Singh

Department of Biochemistry

Kurukshetra University

Kurukshetra, Haryana 136119 (India)

Tel. +91 1744238 196, Fax +91 1744238 277, E-Mail jasbirdhanda@gmail.com 
carrier rate in India ranges from 1 to $13 \%$, with a national average of $4.7 \%$. Vertical and horizontal transmission in the perinatal period and early childhood, respectively, are the major means of transmission of this infection in India [5]. There is increasing evidence that the clinical outcome, response to antiviral treatment and long-term prognosis may differ depending on the genotype of the patient [6]. An attempt has been made in this communication to study different genotype, subgenotype and serotype distribution, precore mutations and to carry out phylogenetic analysis of HBV in Haryana (North India), as there is a lack of information from this area.

The sera were obtained from $21 \mathrm{HBsAg}$-positive patients from Haryana who had not taken antiviral agents such as lamivudine or interferon. All patients were negative for HIV and the hepatitis $\mathrm{C}$ virus infection. The institute's ethics committee approved the study. Alanine aminotransminase (ALT) and HBeAg were determined in all the serum samples using an auto-analyzer and commercially available kits (Abbotts Diagnostics), respectively. The extraction of DNA from serum was performed using a QIAmp extraction kit (Qiagen, Germany). DNA extracted was eluted in $100 \mu \mathrm{l}$ best quality water.

PCR for the amplification of the pre-S1/S2 region was done using nested PCR utilizing 230F (5'-TCACAATACCGCAGAGTCT- $3^{\prime}$ ) and 800R (5'-AACAGCGGTATAAAGGGACT-3') primers for the first round. PCR was performed for 40 cycles involving denaturation at $94^{\circ}$ for $1 \mathrm{~min}$, annealing at $53^{\circ}$ for $50 \mathrm{~s}$ and extension at $72^{\circ}$ for $50 \mathrm{~s}$. The initial denaturation was at $94^{\circ}$ for $3 \mathrm{~min}$, and final extension was performed at $72^{\circ}$ for $10 \mathrm{~min}$. Second-round PCR was performed using P7 (5'-GTGGTGGACTTCTCTCAATTTTC-3') and P8 (5'-CGGTATAAAGGGACTCAAGAT-3') primers, as per the method of Lindh et al. [7]. Genotyping was done using the restriction enzymes HinfI and Tsp509I, again as per the method of Lindh et al. [7].

The precore region was amplified using nested PCR involving primers 1732F (5'-CTGGGAGGAGTTGGGGGA-3') and 2045R (5'-CAATGCTCAGGAGACTCTAACGG-3') for the first round. PCR was performed for 40 cycles involving denaturation at $94^{\circ}$ for $30 \mathrm{~s}$, annealing at $62^{\circ}$ for $50 \mathrm{~s}$ and extension at $72^{\circ}$ for $50 \mathrm{~s}$. Initial denaturation was at $94^{\circ}$ for $5 \mathrm{~min}$ and final extension was performed at $72^{\circ}$ for $10 \mathrm{~min}$. Second round PCR was performed using primers 1765F (5'-GGTCTTTGTACTAGGAGGCTG-3') and 1968R (5'-GTCAGAAGGCAAAAACGAGAG-3'). PCR was performed for 40 cycles involving denaturation at $94^{\circ}$ for $30 \mathrm{~s}$, annealing at $58^{\circ}$ for $50 \mathrm{~s}$ and extension at $72^{\circ}$ for $50 \mathrm{~s}$. Initial denaturation was at $94^{\circ}$ for $5 \mathrm{~min}$, and final extension was performed at $72^{\circ}$ for $10 \mathrm{~min}$. The results were analyzed on a $2 \%$ agarose gel.

Nucleotide sequences of samples were compared with the available wild-type sequences using BioEdit sequence comparison software (USA). A phylogenetic analysis was carried out as described previously [8].

Assays of ALT and HBeAg showed that $24 \%$ of the samples had elevated ALT levels and $90 \%$ of the samples were negative for $\mathrm{HBeAg}$. The banding pattern of nested PCR (using $230 \mathrm{~F}$ and $800 \mathrm{R}$ primers in the first round and P7 and P8 primers in the second round, followed by restriction analysis using HinfI and Tsp509I for genotyping) was compared with the published results of Lindh et al. [7]. Our results showed that $15 / 17$ (90\%) of the samples were of the HBV D genotype (subgenotype D1, serotype ayw2), 1 sample (5\%) belonged to subgenotype A1 (serotype $a d w 2)$ and the remaining $1(5 \%)$ to HBV E genotype (serotype ayw4). Genotype A was found to have subgenotype A1 quite similar to the South African isolates. Results for genotyping were confirmed using phylogenetic analysis and are shown in figure 1 . This is the first report of the presence of the HBV E genotype in India, as this genotype is characteristic of West Africa [8]. Our results do not support the previous finding of Thakur et al. [9] in which genotypes D and A were detected in 48 and $46 \%$ of the individuals, respectively, in the Indian subcontinent. Similar to our findings, Thippavazzula et al. [10] reported that genotype D (subgenotype D1, serotype ayw) and genotype A (subgenotype A1, serotype ayw) were prevalent in a South Indian population. Banerjee et al. [11] had reported genotype D having subgenotypes D1, D3 and D5 as well as serotypes ayw 2 and ayw 3 in eastern India.

Amplification and sequencing of the precore region shows $1762^{\mathrm{A}-\mathrm{T}}$ and $1764^{\mathrm{G}-\mathrm{A}}$ mutations. A $1762^{\mathrm{A}-\mathrm{T}}$ mutation was observed in $38 \%$ of the samples; $5 \%$ had elevated ALT levels, and $85 \%$ of the samples were negative for HBeAg. A $1764^{\mathrm{G}-\mathrm{A}}$ mutation was observed in $15 \%$ of the samples, and $10 \%$ had elevated ALT and were negative for HBeAg. $1762^{\mathrm{A}-\mathrm{T}}$ and $1764^{\mathrm{G}-\mathrm{A}}$ mutations were higher in negative $\mathrm{HBeAg}$ and equally common in different genotypes, but with high ALT as observed by Chauhan et al. [12]. 1762 ${ }^{\mathrm{A}-\mathrm{T}}$ and $1764^{\mathrm{G}-\mathrm{A}}$ mutations suppress $\mathrm{HBeAg}$ synthesis and may contribute to hepatocarcinogenesis $[13,14]$. An $1809^{\mathrm{T}}$ mutation was observed in 5\% of Indian patients under study, all of whom had normal ALT and negative HBeAg. This is a missense mutation, which is found in $80 \%$ of African blacks [14] and represents the wild-type.

Therefore, this communication reports the first instance of HBV genotype $\mathrm{E}$ in an Indian population. The 
Fig. 1. Phylogenetic analysis of $S$ region position 375-790 from the EcoRI site on AY945307. Names of isolates sequenced in the present study are surrounded by boxes.

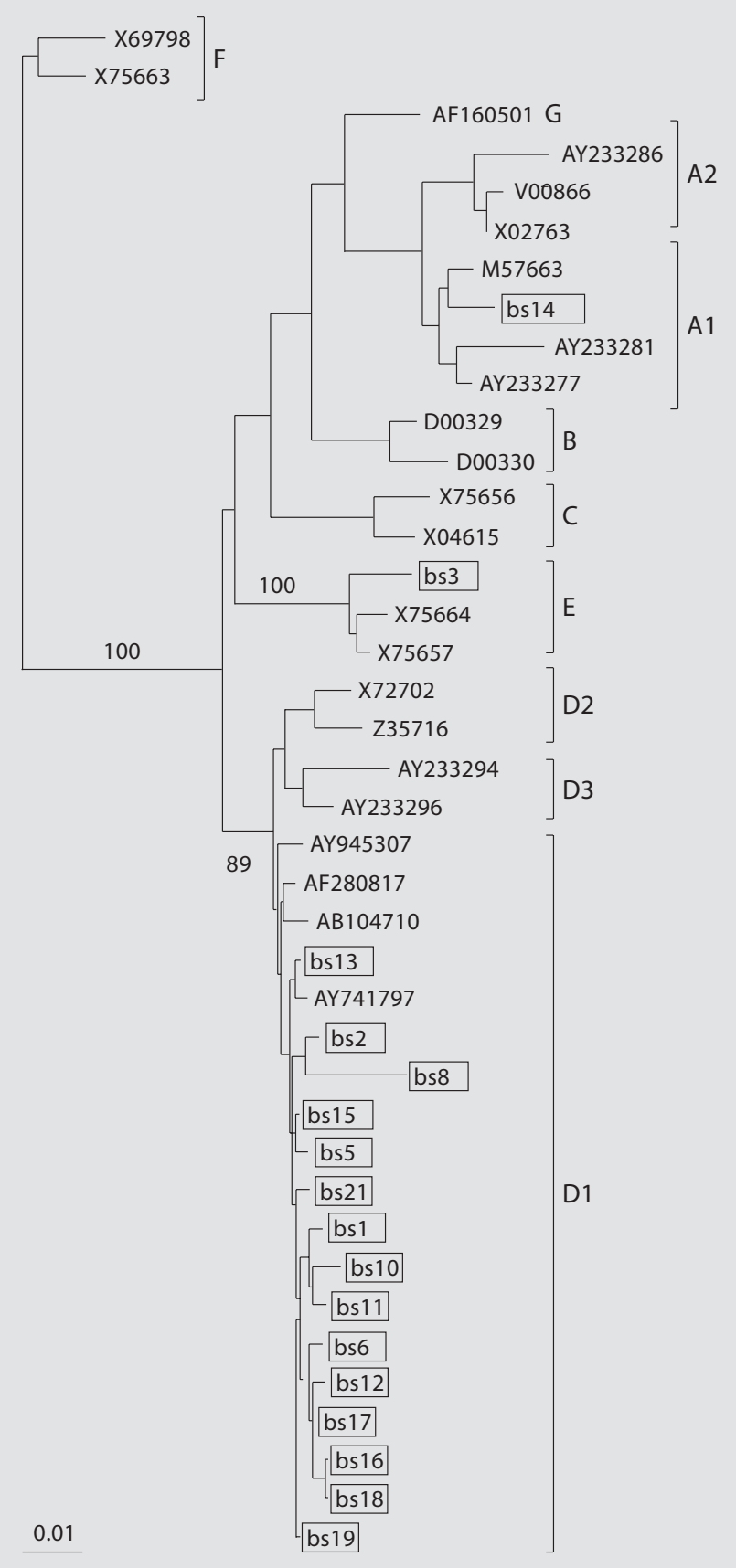

majority of the samples have HBV D genotypes, subgenotype D1 and serotype ayw2. $1762^{\mathrm{A}-\mathrm{T}}$ and $1764^{\mathrm{G}-\mathrm{A}}$ as well as $1809^{\mathrm{T}}$ mutations have also been observed. Efforts to amplify and sequence the full length genotype $\mathrm{E}$ are ongoing.

Hepatitis B Virus Genotype E in India

\section{Acknowledgement}

Jasbir Singh is thankful to the Union of International Cancer Congress for providing financial assistance to carry out this work. 


\section{References}

- 1 Sugauchi F, Mizokami M, Orito E, Ohno T, Hayashi K, Kato T, Tanaka Y, Kato H, Ueda $\mathrm{R}$ : Molecular evolutionary analysis of the complete nucleotide sequence of Hepatitis B Virus (HBV) in a case of HBV infection acquired through a needle stick accident. Clin Infect Dis 2000;31:1195-1201.

-2 Stuyver L, De Gendt S, Van Geyt C, Zoulim F, Fried M, Schinazi RF, Rossau R: A new genotype of hepatitis B virus: complete genome and phylogenetic relatedness. J Gen Virol 2000;81:67-74.

- 3 Arauz-Ruiz P, Norder H, Robertson BH, Magnius LO: Genotype H: a new Amerindian genotype of hepatitis $B$ virus revealed in Central America. J Gen Virol 2002;83:20592073.

-4 Norder H, Courouce AM, Coursaget P, Echevarria JM, Lee SD, Mushahwar IK, Robertson BH, Locarnini S, Magnius LO: Genetic diversity of hepatitis B virus strains derived worldwide: genotypes, subgenotypes and HBsAg subtypes. Intervirology 2004; 47: 289-309.
5 Thyagarajan SP, Jayaram S, Mohanavalli B: Prevalence of $\mathrm{HBV}$ in the general population in India; in Sarin SK, Singhal AK (eds): Hepatitis B in India: Problems and Prevention. New Delhi, CBS Publishers, 1996, p 16.

-6 Kidd-Ljunggren K, Miyakawa Y, Kidd AH: Genetic variability in hepatitis B viruses. J Gen Virol 2002;83:1267-1280.

7 Lindh M, Andersson AS, Gusdal A: Genotypes, nt 1858 variants, and geographic origin of hepatitis B virus: large-scale analysis using a new genotyping method. J Infect Dis 1997;175:1285-1293.

8 Kramvis A, Kew MC: Epidemiology of hepatitis B virus in Africa, its genotypes and clinical associations of genotypes. Hepatol Res 2007;37:S9-S19

-9 Thakur V, Guptan RC, Kazim SN, Malhotra V, Sarin SK: Profile, spectrum and significance of HBV genotypes in chronic liver disease patients in Indian subcontinent. J Gastroenterol Hepatol 2002;17:165-170.

- 10 Thippavazzula R, Mogili C, Chandra M, Khaja MN, Habeeb MA, Habibullah CM: Prevalent HBV genotypes and subtypes in a South Indian population. J Clin Virol 2006; 37:58-64.
11 Banerjee A, Kurbanov F, Datta S, Chandra PK, Tanaka Y, Mizokami M, Chakravarty R: Phylogenetic relatedness and genetic diversity of hepatitis B virus isolates in Eastern India. J Med Virol 2006;78:1164-1174.

12 Chauhan R, Kazim SN, Bhattacharjee J, Sakhuja P, Sarin SK: Basal core promoter, precore region mutations of $\mathrm{HBV}$ and their association with e antigen, genotype, and severity of liver disease in patients with chronic hepatitis B in India. J Med Virol 2006;78: 1047-1054.

13 Takahashi K, Akahane Y, Hino K, Ohta Y, Mishiro S: Hepatitis B virus genomic sequence in the circulation of hepatocellular carcinoma patients: comparative analysis of 40 full-length isolates. Arch Virol 1998;143: 2313-2326.

14 Baptista M, Kramvis A, Kew MC: High prevalence of $1762(\mathrm{~T}) 1764(\mathrm{~A})$ mutations in the basic core promoter of hepatitis B virus isolated from black Africans with hepatocellular carcinoma compared with asymptomatic carriers. Hepatology 1999;29:946-953. 